ACTA UNIVERSITATIS NICOLAI COPERNICI DOI: http://dx.doi.org/10.12775/AUNC_ECON.2014.017 EKONOMIA XLV nr 2 (2014) 275-288

Pierwsza wersja złożona 26 czerwca 2014

ISSN

Końcowa wersja zaakceptowana 20 grudnia 2014

2080-0339

\title{
Eliza Buszkowska*
}

\section{DYNAMIKA PRZEPŁYWÓW INWESTYCJI POMIĘDZY GIEŁDAMI**}

Z a ry s treści. W pracy starano się odpowiedzieć na liczne pytania dotyczące przepływów inwestycji pomiędzy giełdami. Zastanowiono się, czy giełdy to system naczyń połączonych, czy następuje ucieczka z jednych giełd i lokowanie środków na innych. Czy w różnych okresach bardziej traciły na giełdzie małe firmy, czy duże i średnie? Badano związki między reakcjami różnych instrumentów finansowych na tę samą informację za pomocą modeli dynamicznych korelacji warunkowych. Sprawdzono, jaka była reakcja na impuls z rynku amerykańskiego w zależności od wielkości spółek na całym świecie. Badanie objęło przede wszystkim okres kryzysu subprime.

S ł o w a k 1 u c z o w e: indeksy giełdowe, zmienność, modele DCC, funkcja odpowiedzi na impuls.

K l a s y fik a j a J E L: C10.

Autorka dziękuje Recenzentowi za uwagi, które pozwoliły znacząco podnieść wartość artykułu, oraz osobie, która chce pozostać anonimowa, za zgodę na wykorzystanie większości pytań postawionych w tej pracy.

*Adres do korespondencji: Eliza Buszkowska, Uniwersytet im. Adama Mickiewicza w Poznaniu, al. Niepodległości 53,61-714 Poznań, e-mail: eliza_b2@o2.pl.

** Praca finansowana przez Wydział Prawa i Administracji Uniwersytetu im. Adama Mickiewicza w Poznaniu.

(C) 2014 Uniwersytet Mikołaja Kopernika. All rights reserved.

http://www.aunc.ekonomia.umk.pl 


\section{WSTĘP}

W ciągu ostatnich lat nastapił znaczny rozrost systemów finansowych i ich powiązań w skali globalnej. Wzrosło ryzyko inwestycji związane $\mathrm{z}$ inwestowaniem na całym świecie, a także możliwość dywersyfikacji portfela inwestycji (Doman, Doman, 2014). Zmieniła się budowa rynków finansowych. Nastąpiła „liberalizacja handlu, postęp technologiczny, zwłaszcza w przepływie informacji oraz gwałtowny rozwój i wzrost gospodarczy w największych gospodarkach wschodzących", $\left({ }^{1}\right)$, (Półkarz, 2013). Do pozytywnych skutków globalizacji systemu finansowego należy zaliczyć, zgodnie z pozycją $\left({ }^{1}\right)$, swobodne przepływy kapitału, bardziej odpowiedzialną politykę fiskalną i pieniężną, a także powstanie nowych modeli $\mathrm{i}$ instrumentów finansowych. Autorzy wskazują też na negatywy tego zjawiska: ryzykowną nieprzewidywalność zachowań inwestorów, „bańki spekulacyjne" na międzynarodową skalę i ryzyko zarażenia. Dodatkowym negatywnym skutkiem globalizacji rynków finansowych mogą być bolesne konsekwencje kryzysów finansowych ze względu na ogromny wzrost kapitału w systemie finansowym i wspomniane zjawisko zarażania. Tematem tego artykułu jest kryzys subprime, który miał miejsce w okresie 2007-2009. Kryzys ten wywołał poważne skutki finansowe i gospodarcze, między innymi osłabienie gospodarek wielu krajów, w tym Chin i USA. Skłonił do dyskusji na temat niewłaściwego zarządzania ryzykiem, potrzeby stworzenia lepszych regulacji systemu finansowego oraz problemu niskiej etyki, spotęgowanej znanym dokumentem Charlesa $\mathrm{H}$. Fergusona z roku 2010 na temat anatomii kryzysu subprime. Należy dobrze poznać charakterystykę tego okresu na rynkach finansowych, żeby móc lepiej zarządzać ryzykiem w przypadku podobnych katastrof w przyszłości.

Dokładnie rzecz ujmując, celem tego artykułu jest odpowiedź na pytania często nurtujące analityków giełdowych i zadawane na forach internetowych przez inwestorów giełdowych. Wszystkie te wątpliwości dotyczą przede wszystkim specyfiki kryzysu subprime. Autorka wymieni je kolejno. Czy w różnych okresach, w tym podczas kryzysu hipotecznego giełdy światowe działały jak system naczyń połączonych, to znaczy, czy rynek zachowywał się podobnie, czy przeciwnie - jedne notowania umacniały się, podczas gdy inne traciły? Jest to problem zbliżony do zagadnienia zarażania rynków (patrz R. Karkowska ${ }^{2}$ ). Zjawisko to Bank Światowy definiuje trojako. Jedna z definicji mówi, że z zarażaniem mamy do czynienia, gdy w czasie kryzysu

\footnotetext{
${ }^{1}$ Praca dostępna na stronie http://www.inwestycjewinnowacje.pl/czytaj,1143,globalnerynki-finansowe.html.

${ }^{2}$ Praca dostępna na stronie: http://jmf.wzr.pl/pim/2012_2_1_6.pdf.
} 
korelacja między gospodarkami jest silniejsza niż w okresie spokoju (P. Dobrzański ${ }^{3}$ ). Autorka uwzględni jednak znak współczynnika korelacji, który będzie świadczył o podobnym bądź odmiennym zachowaniu się badanych indeksów giełdowych, a nie wyłącznie siłe powiązań, jak to się czyni w przypadku badania zarażania (Burzała, 2013). Kolejne pytania brzmią: czy w czasie kryzysu następowała ucieczka $\mathrm{z}$ giełdy polskiej na giełdy zagraniczne? Czy w wyróżnionym okresie bardziej traciły na giełdach małe firmy, czy duże i średnie? Czy w czasie kryzysu były zauważalne silniejsze związki między reakcjami różnych instrumentów finansowych na tę samą informację? Jaka była reakcja instrumentów finansowych na impuls z rynku amerykańskiego w zależności od wielkości spółek? W tym artykule między innymi autorka kontynuuje podjętą w literaturze dyskusję nad powiązaniami w okresie kryzysu subprime (Doman, Doman, 2014), ale koncentruje się na korelacjach dla szeregów niestacjonarnych. Sądzi bowiem, że z punktu widzenia inwestora współwystępowanie na wykresie może być równie ważne jak zależności przyczynowo-skutkowe. Te ostatnie nie będą brane pod uwagę ze względu na spowodowaną niestacjonarnością wykorzystanych szeregów czasowych możliwość otrzymania korelacji pozornych.

\section{HIPOTEZY BADAWCZE}

Autorka stawia hipotezy badawcze, które dotyczą sformułowanych wcześniej pytań. Pierwsza z nich głosi, że w czasie kryzysu giełdy światowe działały jak system naczyń połączonych, to znaczy rynek międzynarodowy zachowywał się podobnie, gdyż kryzys objął praktycznie cały świat i na wszystkich giełdach dominowały spadki głównych indeksów. $Z$ tego samego powodu nie istniała, zdaniem autorki, ucieczka $\mathrm{z}$ giełdy polskiej na giełdy innych krajów, jeżeli za główny wskaźnik całego rynku przyjmie się indeks największych spółek. Autorka sądzi, że w czasie kryzysu bardziej traciły małe firmy niż duże i średnie, gdyż w firmach dużych istnieją bardziej rozbudowane systemy zarządzania ryzykiem. $Z$ drugiej strony duże spółki są narażone na większe straty bezwzględne, a także są częściej wybierane przez inwestorów grających „na spadki”, zatem wydaje się, że powinny bardziej tracić na giełdzie w okresach dużych niepokojów. Autorka stawia hipotezę, że w czasie kryzysu nie były zauważalne silniejsze związki między reakcjami różnych instrumentów finansowych na tę samą informację, gdyż jak wiadomo z literatury, nie istniały w większości istotne korelacje warunkowe dla stóp zwrotu w tym okresie. $Z$ drugiej strony coraz szybszy przepływ infor-

\footnotetext{
${ }^{3}$ Praca dostępna na stronie: http://www.bibliotekacyfrowa.pl/Content/35547/009.pdf.
} 
macji pomiędzy rynkami mógł spowodować zwiększenie tych powiązań. Autorka sądzi, że na impuls indeksu DJ najsilniej odpowiedziały spółki należące do indeksów małych spółek, gdyż wydają się mniej stabilne i bardziej wrażliwe na sygnały z rynku niż spółki duże. Powyższe hipotezy zostaną zweryfikowane w oparciu o narzędzia ekonometryczne.

\section{DANE}

W badaniach wykorzystano dzienne notowania instrumentów finansowych w okresie kryzysu: od 8 sierpnia 2007 do 10 marca 2009 roku oraz w okresie po kryzysie subprime (w czasie kryzysu dłużnego), tj. od 11 marca 2009 do 14 czerwca 2013 roku pochodzące z serwisu stooq.pl. Ramy czasowe kryzysu ustalono na podstawie analizy 1- i 3-miesięcznych spreadów LIBOR-OIS. Jak wiadomo, spready zachowują się przeciwnie do indeksów giełdowych. W okresie od 8 sierpnia 2007 do 10 marca 2009 roku spready zaczęły rosnąc i ten proces skończył się 11 marca 2009 roku, kiedy to zaczęły maleć (Płuciennik, 2013). (Tablice korelacji dla pierwszych różnic wyznaczono dla okresu kryzysu od 14 sierpnia 2007 do 10 marca 2009 roku i okresu po kryzysie od 17 marca 2009 do 14 czerwca 2013 roku).

\section{METODYKA BADANIA}

Hipotezy zweryfikowano na podstawie badań empirycznych, opartych na metodach ekonometrycznych. W analizie empirycznej zastosowano funkcje odpowiedzi na impuls, dynamiczne modele warunkowych korelacji i współczynniki korelacji liniowej dla szeregów czasowych, które wykorzystują związki liniowe między tendencjami rozwojowymi. Współczynniki korelacji zostały obliczone metodą dla pierwszych różnic, wyrażoną poniższym wzorem:

$$
r(\Delta x \Delta y)=\frac{\sum_{i=2}^{N}\left(\Delta x_{t}-\Delta \bar{x}\right)\left(\Delta y_{t}-\Delta \bar{y}\right)}{(N=1) \sigma_{\Delta x} \sigma_{\Delta y}},
$$

gdzie $\Delta x_{t}$ oznacza pierwszą różnicę w chwili t, a $\sigma_{\Delta x}$ - odchylenie standardowe odpowiedniego szeregu. Wzór ten daje dla szeregów czasowych dokładniejsze wyniki niż formuła Pearsona (Augustyniak, 2003).

Wykorzystana analiza $I R F$ pozwoliła ocenić reakcję pojedynczej zmiennej na jednostkową zmianę innej zmiennej (Baillie, 2013; Kliber i in., 2012). $\mathrm{W}$ analizie impulsowej posłużono się modelami wektorowej autoregresji dla szeregów zwrotów logarytmicznych. Obok analizy wpływu zaburzeń na sys- 
tem funkcja odpowiedzi na impuls pozwala zbadać stabilność systemu. Jeśli wartość $I R F$ są zbieżne (impuls wygasa, a nie utrzymuje się w nieskończoność), to modelowany system jest stabilny i ma stacjonarne zmienne (Kusideł, 1999).

Do opisu szeregów zwrotów logarytmicznych poziomów indeksów giełdowych wykorzystano wprowadzony przez Engle'a (2002) model DCC $(p, q)$ - model dynamicznej korelacji warunkowej, opisany w wielu pracach (Doman, Doman, 2009; Buszkowska, Płuciennik, 2013), oraz uproszczony NC model Tse i Tsui (1999) przedstawiony na przykład w pracy Minović ${ }^{4}$.

Model DCC Engle'a jest to model dynamicznych korelacji warunkowych, elastyczny, generujący dobre wyniki empiryczne (Doman, Doman, 2009). Ponadto wykorzystuje informacje o korelacjach wyznaczonych na wcześniejszych etapach obliczeń, czyli główną ideę modelu GARCH. Autorka krótko przedstawi oba wykorzystane modele. Niech $r$ będzie wektorem zwrotów, a D macierzą diagonalną z odchyleniem standardowym na diagonali głównej. Kowariancja warunkowa opisana jest za pomocą poniższego równania:

$$
\mathbf{r}_{t} / F_{t-1} \sim F\left(0, \mathbf{H}_{t}\right), \quad \mathbf{H}_{t}=\mathbf{D}_{t} \mathbf{R}_{t} \mathbf{D}_{t} .
$$

Model Tse i Tsui (2002) przedstawiony na przykład w pracy Minović jest szczególnym przypadkiem modelu DCC zmiennych w czasie korelacji warunkowych. Poczyńmy założenia:

$$
\bar{R}=\frac{1}{T} \sum_{t=1}^{T} \boldsymbol{\varepsilon}_{t} \boldsymbol{\varepsilon}_{t}{ }^{\prime} \quad \boldsymbol{\varepsilon}_{t} \equiv \mathbf{D}_{t}^{-1} \mathbf{r}_{t}, \quad E_{t-1}\left(\boldsymbol{\varepsilon}_{t} \boldsymbol{\varepsilon}_{t}{ }^{\prime}\right)=\mathbf{R}_{t},
$$

gdzie $\mathbf{R}_{t}$ jest zmienną w czasie macierzą korelacji. Wtedy model Tse i Tsui (2002) opisuje korelację następująco:

$$
\begin{aligned}
& \mathbf{R}_{t}=\bar{R}\left(1-\theta_{1}-\theta_{2}\right)+\theta_{1} \hat{r}_{t-1}^{k}+\theta_{2} \mathbf{R}_{t-1}, \\
& \hat{r}_{t}^{k}=\operatorname{diag}\left[\frac{1}{k} \sum_{s=t-k}^{t} \boldsymbol{\varepsilon}_{s} \boldsymbol{\varepsilon}_{s}^{\prime}\right]^{-1 / 2}\left[\frac{1}{k} \sum_{s=t-k}^{t} \boldsymbol{\varepsilon}_{s} \boldsymbol{\varepsilon}_{s}^{\prime}\right] \operatorname{diag}\left[\frac{1}{k} \sum_{s=t-k}^{t} \boldsymbol{\varepsilon}_{s} \boldsymbol{\varepsilon}_{s}^{\prime}\right]^{-1 / 2} .
\end{aligned}
$$

Modeluje zmienną w czasie korelację warunkową jako średnią ważoną trzech macierzy korelacji. Przeprowadźmy następującą dekompozycję macierzy $\mathbf{R}_{t}$ :

\footnotetext{
4 Minović J., Modeling Multivariate Volatility Processes:Theory and Evidence, http://store.ectap.ro/ articole/385.pdf.
} 


$$
\begin{aligned}
& \mathbf{R}_{t}=\left(\mathbf{Q}_{t}^{*}\right)^{-1 / 2}\left\{\mathbf{Q}_{t}\right\}\left(\mathbf{Q}_{t}^{*}\right)^{-1 / 2}, \\
& \mathbf{Q}_{t}^{*}=\operatorname{diag} \mathbf{Q}_{t}
\end{aligned}
$$

wtedy wykorzystany w pracy model DCC można zapisać następująco:

$$
\mathbf{Q}_{t}=\bar{R}+\sum_{i=1}^{p} \alpha_{i}\left(\boldsymbol{\varepsilon}_{t-i} \boldsymbol{\varepsilon}_{t-i}^{\prime}-\bar{R}\right)+\sum_{i=1}^{q} \beta_{i}\left(\mathbf{Q}_{t-i}-\bar{R}\right) .
$$

O parametrach $\alpha_{i}, \beta_{j}$ zakładamy, że są skalarne nieujemne i spełniają warunek stacjonarności modelu:

$$
\sum_{i=1}^{p} \alpha_{i}+\sum_{i=1}^{q} \beta_{j}<1
$$

\section{WYNIKI EMPIRYCZNE}

Poniższa tabela przedstawia wartości współczynnika korelacji liniowej obliczone ze wzoru dla szeregów czasowych w okresie kryzysu subprime. Aby wykluczyć korelacje nonsensowne (pozorne), analizę przeprowadzono dla szeregów zróżnicowanych. Stacjonarność stwierdzono na podstawie testu KPSS, w programie GRETL. Jeżeli jednokrotne różnicowanie nie spowodowało stacjonarności zastosowano drugie różnice. Wytłuszczonym drukiem zaznaczono wartości większe od korelacji obliczonych dla okresu spokoju. Jest ich 53\%, bez uwzględnienia elementów różniących się od pozostałych, tzn. drugich różnic dla HSI oraz sWIG80.

Tabela 1. Wartości współczynnika korelacji liniowej w okresie kryzysu suprime

\begin{tabular}{ccccccccccc}
\hline & dWI80 & dAEX & dDJI & dS\&P500 & dNASDAQ & dDAX & dFTSE & dCAC40 & dNIKKEI & ddHSI \\
\hline dWIG80 & 1 & 0,66 & 0,43 & 0,48 & 0,47 & 0,50 & 0,61 & 0,59 & 0,59 & 0,57 \\
dAEX & & 1 & 0,73 & 0,78 & 0,59 & 0,69 & 0,93 & 0,95 & 0,80 & 0,66 \\
dDJI & & & 1 & 0,97 & 0,65 & 0,53 & 0,71 & 0,75 & 0,63 & 0,54 \\
dS\&P500 & & & & 1 & 0,66 & 0,51 & 0,73 & 0,77 & 0,65 & 0,58 \\
dNASDAQ & & & & & 1 & 0,80 & 0,53 & 0,59 & 0,56 & 0,33 \\
dDAX & & & & & & 1 & 0,68 & 0,74 & $\mathbf{0 , 6 3}$ & 0,44 \\
dFTSE & & & & & & 1 & 0,93 & 0,75 & 0,63 \\
dCAC40 & & & & & & & 1 & $\mathbf{0 , 7 9}$ & 0,64 \\
dNIKKEI & & & & & & & & 1 & 0,73 \\
ddHSI & & & & & & & & & 1 \\
\hline
\end{tabular}

Źródło: opracowanie własne. 
Tabela 2. Wartości współczynnika korelacji liniowej w okresie po kryzysie suprime

\begin{tabular}{ccccccccccc}
\hline & ddWIG80 & dAEX & dDJI & dS\&P500 & dNASDAQ & dDAX & dFTSE & dCAC40 & dNIKKEI & dHSI \\
\hline ddWIG80 & 1 & 0,42 & 0,38 & 0,40 & 0,38 & 0,43 & 0,43 & 0,44 & 0,12 & 0,23 \\
dAEX & & 1 & 0,71 & 0,71 & 0,66 & 0,90 & 0,89 & 0,94 & 0,39 & 0,47 \\
dDJI & & & 1 & 0,98 & 0,88 & 0,72 & 0,73 & 0,73 & 0,27 & 0,29 \\
dS\&P500 & & & & 1 & 0,92 & 0,71 & 0,73 & 0,73 & 0,26 & 0,32 \\
dNASDAQ & & & & & 1 & 0,70 & 0,69 & 0,68 & 0,27 & 0,33 \\
dDAX & & & & & & 1 & 0,88 & 0,92 & 0,37 & 0,44 \\
dFTSE & & & & & & & 1 & 0,90 & 0,38 & 0,49 \\
dCAC40 & & & & & & & 1 & 0,37 & 0,45 \\
dNIKKEI & & & & & & & & 1 & 0,57 \\
dHSI & & & & & & & & & \\
\hline
\end{tabular}

Źródło: opracowanie własne.

Pojawiła się tylko jedna wartość nieistotna. Nie występowały istotne ujemne wartości współczynnika korelacji.

Tabela 3 przedstawia wartości współczynnika korelacji liniowej obliczone ze wzoru dla szeregów czasowych w okresie kryzysu subprime dla szeregów notowań.

Tabela 3.Wartości współczynnika korelacji liniowej w okresie kryzysu suprime

\begin{tabular}{ccccccccccc}
\hline & WIG80 & AEX & DJI & S\&P500 & NASDAQ & DAX & FTSE & CAC40 & NIKKEI & HSI \\
\hline WIG80 & 1 & $\mathbf{0 , 6 5}$ & 0,36 & 0,48 & $\mathbf{0 , 4 6}$ & $\mathbf{0 , 5}$ & $\mathbf{0 , 6 0}$ & 0,59 & $\mathbf{0 , 5 8}$ & $\mathbf{0 , 5 6}$ \\
AEX & & 1 & 0,62 & $\mathbf{0 , 7 7}$ & 0,59 & $\mathbf{0 , 6 8}$ & $\mathbf{0 , 9 2}$ & 0,94 & $\mathbf{0 , 7 9}$ & $\mathbf{0 , 6 6}$ \\
DJI & & & 1 & 0,81 & 0,54 & $\mathbf{0 , 4 4}$ & 0,59 & 0,62 & $\mathbf{0 , 5 2}$ & $\mathbf{0 , 4 5}$ \\
S\&P500 & & & & 1 & 0,66 & $\mathbf{0 , 5 1}$ & 0,72 & $\mathbf{0 , 7 7}$ & $\mathbf{0 , 6 5}$ & $\mathbf{0 , 5 7}$ \\
NASDAQ & & & & & 1 & $\mathbf{0 , 7 9}$ & 0,53 & 0,57 & $\mathbf{0 , 5 6}$ & 0,33 \\
DAX & & & & & & 1 & $\mathbf{0 , 6 7}$ & $\mathbf{0 , 7 4}$ & $\mathbf{0 , 6 3}$ & $\mathbf{0 , 4 4}$ \\
FTSE & & & & & & & 1 & $\mathbf{0 , 9 2}$ & $\mathbf{0 , 7 4}$ & $\mathbf{0 , 6 3}$ \\
CAC40 & & & & & & & & 1 & $\mathbf{0 , 7 9}$ & $\mathbf{0 , 6 4}$ \\
NIKKEI & & & & & & & & & 1 & $\mathbf{0 , 7 3}$ \\
HSI & & & & & & & & & 1 \\
\hline
\end{tabular}

Źródło: opracowanie własne.

Wytłuszczonym drukiem zaznaczono wartości większe od wartości współczynnika korelacji obliczonych dla okresu spokoju. Jest ich 65\%. Nie było wówczas nieistotnych korelacji. Ponieważ nie był spełniony warunek stacjonarności szeregów czasowych, otrzymane korelacje mogły być pozorne. Nie można zatem w tym przypadku wnioskować o związkach przyczynowo-skutkowych pomiędzy badanymi indeksami giełdowymi. W okresie po kryzysie wartości nieistotnych było $15 \%$.

Zauważa się, że nie występowały istotne ujemne wartości współczynnika korelacji. Zatem nie następowała ucieczka z jednych giełd na inne, a raczej była to ucieczka ze wszystkich giełd, być może w bardziej bezpieczne formy inwestowania. Istotne wartości dodatnie w tabeli świadczą o tym, że w okre- 
sie kryzysu giełda była systemem naczyń połączonych. Traciły na wartości wszystkie indeksy giełdowe.

Tabela 4. Wartości współczynnika korelacji liniowej w okresie po kryzysie

\begin{tabular}{ccccccccccc}
\hline & WIG80 & AEX & DJI & S\&P500 & NASDAQ & DAX & FTSE & CAC40 & NIKKEI & HSI \\
\hline WIG80 & 1 & 0,60 & 0,49 & 0,49 & 0,45 & 0,06 & 0,58 & 0,60 & 0,45 & 0,33 \\
AEX & & 1 & 0,71 & 0,71 & 0,59 & 0,10 & 0,89 & 0,94 & 0,39 & 0,47 \\
DJI & & & 1 & 0,97 & 0,87 & 0,08 & 0,72 & 0,72 & 0,24 & 0,29 \\
S\&P500 & & & & 1 & 0,91 & 0,07 & 0,72 & 0,72 & 0,25 & 0,31 \\
NASDAQ & & & & & 1 & 0,07 & 0,68 & 0,68 & 0,25 & 0,33 \\
DAX & & & & & & 1 & 0,09 & 0,10 & 0,04 & 0,43 \\
FTSE & & & & & & & 1 & 0,90 & 0,37 & 0,49 \\
CAC40 & & & & & & & & 1 & 0,36 & 0,44 \\
NIKKEI & & & & & & & & 1 & 0,17 \\
HSI & & & & & & & & & & \\
\hline
\end{tabular}

Źródło: opracowanie własne.

Zapytano, czy w czasie kryzysu były zauważalne silniejsze związki między reakcjami różnych instrumentów finansowych na tę samą informację. Szacowano modele DCC $(1,1)$ Engle'a oraz Tse i Tsui dla kombinacji następujących szeregów zwrotów logarytmicznych: AEX, DJI, S\&P500, DAX, CAC40, FTSE, NASDAQ100, NIKKEI225, HSI, sWIG80. Indeks sWIG80 był bardzo silnie skorelowany z indeksami mWIG40 i WIG20, zatem mógł być wybrany jako przedstawiciel. Do wymienionych danych dopasowały się prawidłowo wyłącznie następujące dwa modele DCC:

Tabela 5. Model DCC z rozkładem normalnym dla HSI oraz NASDAQ w okresie kryzysu

\begin{tabular}{ccc}
\hline & HSI i NASDAQ & \\
\hline HSI - IGARCH(1,1) & oszacowania parametrów & 0 -value \\
\cline { 2 - 3 }$\alpha_{1}$ & $-0,000994$ & 0,3059 \\
$\beta_{1}$ & 1,000994 & \\
NASDAQ - IGARCH(1,1) & & \\
$\alpha_{1}$ & 0,160132 & 0,0089 \\
$\beta_{1}$ & 0,839868 & 0,0000 \\
$\alpha$ & & \\
$\beta$ & 0,031423 & 0,0006 \\
DCC(1,1)- Engla & 0,968565 & 0,0000 \\
\hline
\end{tabular}

Źródło: opracowanie własne. 
Tabela 6. Model TSE i TSUI z rozkładem normalnym dla HSI oraz CAC40, w okresie kryzysu

\begin{tabular}{ccc}
\hline & HSI i CAC40 & \\
\hline HSI - IGARCH $(1,1)$ & oszacowania parametrów & 0,3059 \\
$\alpha_{1}$ & $-0,0009934(0,009659)$ & \\
$\beta_{1}$ & 1,0009937 & \\
CAC40 - IGARCH(1,1) & & 0,0483 \\
$\alpha_{1}$ & $0,086443(0,043285)$ & \\
$\beta_{1}$ & 0,913557 & 0,0494 \\
DCC(1,1) TSE i TSUI & $0,00906(0,0045589)$ & 0,0000 \\
$\theta_{1}$ & $0,99093(0,027497)$ & \\
$\theta_{2}$ & &
\end{tabular}

Źródło: opracowanie własne.

Były to jedyne instrumenty finansowe, dla których parametry modeli DCC były istotne i nie było korelacji w resztach standaryzowanych i kwadratach reszt standaryzowanych, zatem zweryfikowano je pozytywnie. Jednak nawet dla tych modeli nie był w sposób zadowalający spełniony warunek stacjonarności modelu, gdyż suma parametrów modelu dynamicznych korelacji warunkowych była w przybliżeniu równa jeden. Na podstawie grupy porównywanych modeli wnioskuje się, że w okresie kryzysu subprime nie istniały silne związki między reakcjami wskazanych instrumentów finansowych na tę samą informację.
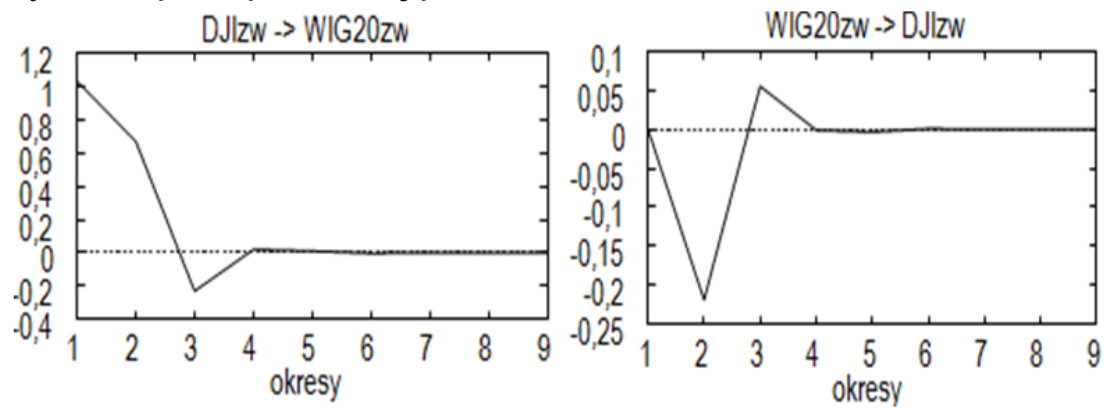

Rysunek 1. Wykres funkcji odpowiedzi na impuls dla pary WIG20 i DJI w okresie kryzysu

Źródło: opracowanie własne.

Zapytano, czy w dwóch różnych okresach małe, średnie i duże spółki reagowały różnie na impuls z rynku amerykańskiego (Miczka i Szulc, 2011). Aby znaleźć na nie odpowiedź, przeprowadzono badanie dla indeksów światowych następujących państw: Francji, Hiszpanii, Niemiec, Belgii, Danii, 
Polski. Dla pozostałych państw indeks małych bądź średnich spółek nie istnieje.
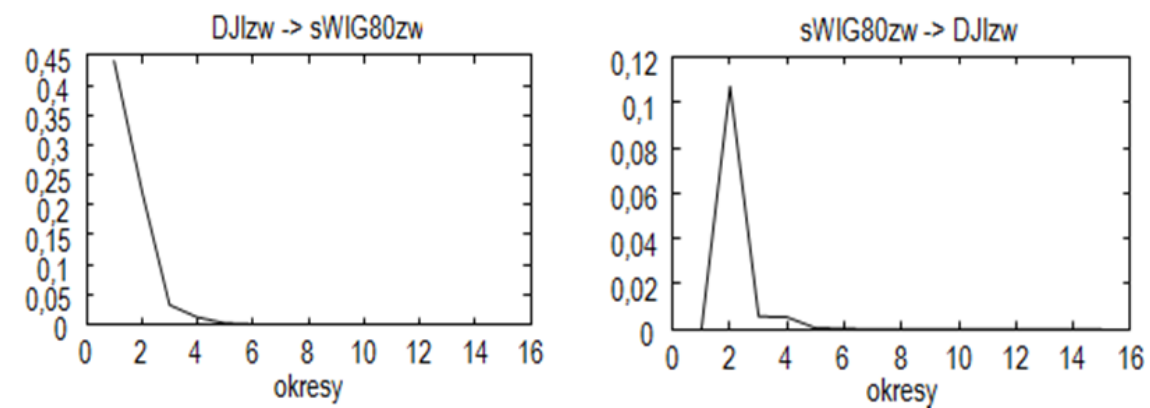

Rysunek 2. Wykres funkcji odpowiedzi na impuls dla pary sWIG80 i DJI w okresie po kryzysie

Źródło: opracowanie własne.
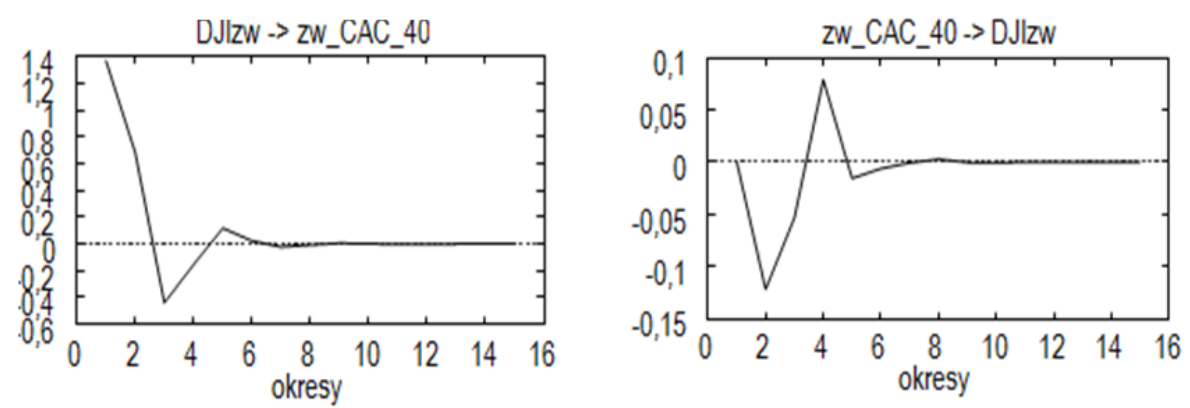

Rysunek 3. Wykres funkcji odpowiedzi na impuls dla pary mWIG40 i DJI w okresie po kryzysie

Źródło: opracowanie własne.

Okazało się, że na zaburzenie wielkości jednego odchylenia standardowego w obu okresach najbardziej reagowały duże spółki z indeksu WIG20, co wnioskuje autorka na podstawie większych wahan wartości funkcji odpowiedzi na impuls i przyjmowaniu przez nią większych wartości co do wartości bezwzględnej. Analizując reakcję indeksu rynku amerykańskiego (Przekota, 2007), wnioskuje się, że najsilniej odpowiedział on na zmienność dużych spółek. Indeksy małych i średnich spółek zareagowały podobnie do siebie. Analogiczną analizę przeprowadzono dla pozostałych wymienionych państw - dla dużych, średnich i małych spółek. Przykładowe wykresy zamieszczono tylko dla Francji. 

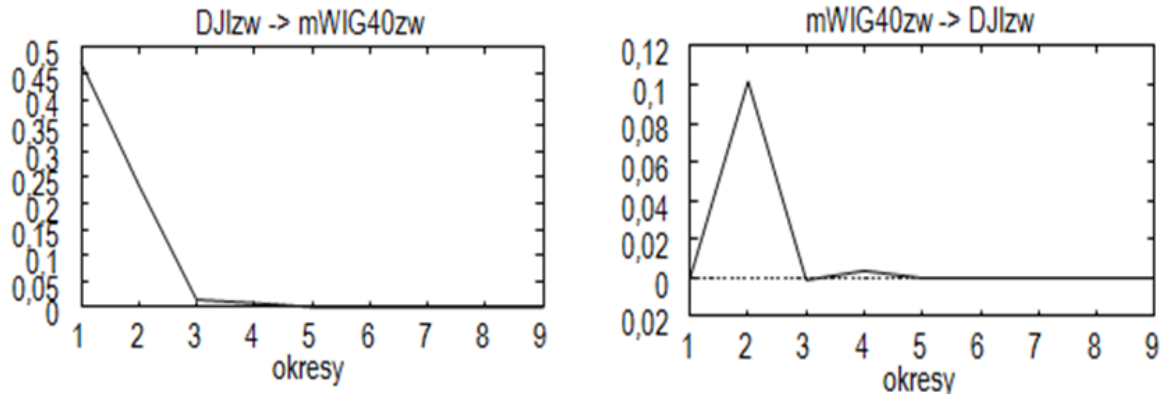

Rysunek 4. Wykres funkcji odpowiedzi na impuls dla pary CAC40 i DJI w okresie kryzysu

Źródło: opracowanie własne.
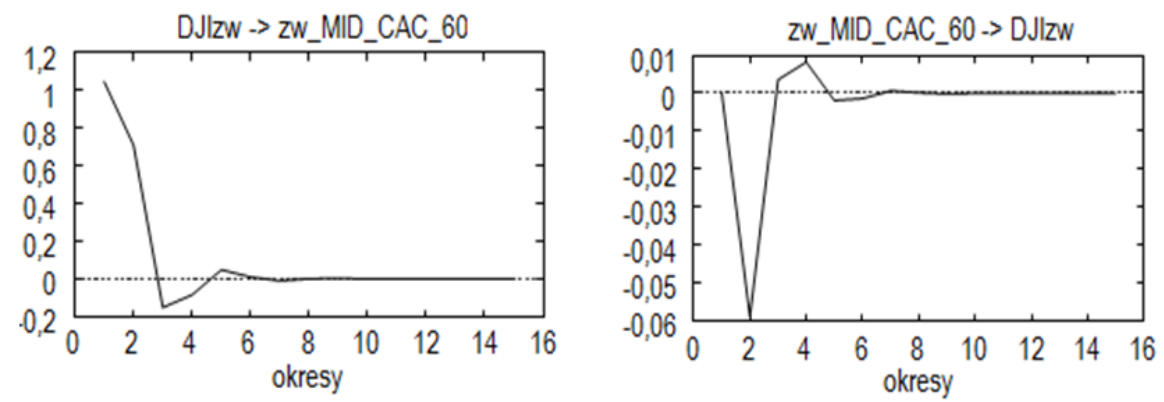

Rysunek 5. Wykres funkcji odpowiedzi na impuls dla pary CAC MID 60 i DJI w okresie kryzysu

Źródło: opracowanie własne.
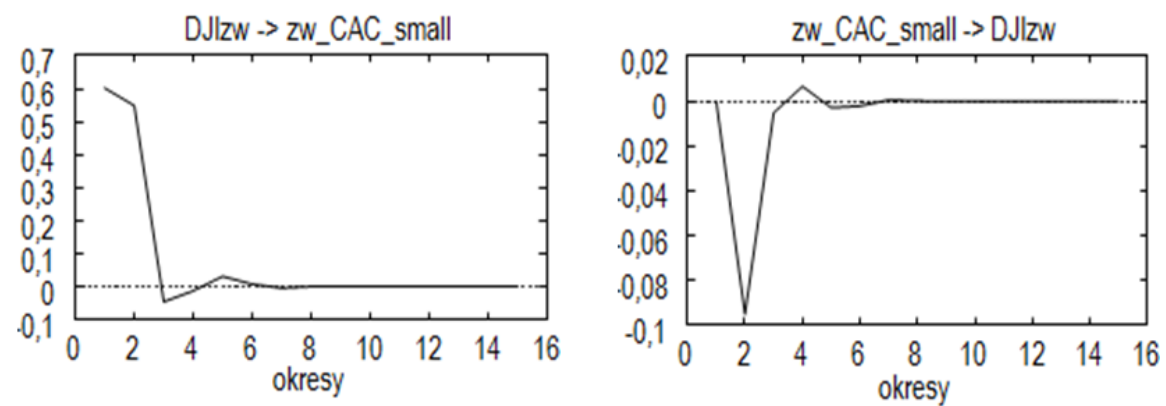

Rysunek 6. Wykres funkcji odpowiedzi na impuls dla pary CAC_small i DJI w okresie kryzys

Źródło: opracowanie własne. 
Z wykresów (zamieszczonych i pozostałych analizowanych w tym badaniu) wynika, że na impuls z rynku amerykańskiego najsilniej w pierwszym okresie zareagowały we wszystkich państwach (dla których istniały rozważane trzy indeksy giełdowe) indeksy dużych spółek, na drugim miejscu średnich, a najsłabiej małych. Indeksy małych spółek nie są najsłabiej skorelowane z indeksem DJI. Współczynniki korelacji Pearsona dla wszystkich indeksów były podobne i wynosiły około 0,5 . Indeks DJI zareagował odrobinę silniej na impulsy spółek dużych niż średnich i małych. Ponieważ impulsy wygasają $\mathrm{w}$ późniejszych okresach, modele wykorzystane $\mathrm{w}$ analizie impulsowej (Juselius, 2009) są stabilne i mają stacjonarne zmienne. Na kolejnym etapie badania postawiono pytanie, czy w czasie kryzysu bardziej traciły na wartości notowania giełdowe małych firm, dużych, czy też średnich? Wyniki prezentuje tabela 7.

Tabela 7. Porównanie wielkości spadków polskich indeksów w okresie kryzysu

\begin{tabular}{cccc}
\hline sWIG80 & \multicolumn{3}{c}{ WIG20 } \\
\hline $\min$ & 6017,25 & $\max$ & 3917,87 \\
$\max$ & 18857 & $\min$ & 1327,64 \\
Różnica bezwzględna & 12839,75 & Różnica bezwzględna & 2590,23 \\
Różnica względna & 2,13 & Różnica względna & 1,95 \\
\hline mWIG40 & & & \\
$\max$ & 4883,47 & & \\
$\min$ & 1228,69 & & \\
Różnica bezwzględna & 3654,78 & & \\
Różnica względna & 2,97 & & \\
\hline
\end{tabular}

Źródło: opracowanie własne.

Względnie najmniej na wartości straciły indeksy dużych spółek. Przyczyną tego może być fakt, że w dużych spółkach najpełniej zarządza się ryzykiem.

Następnie uwzględniono indeksy małych, średnich i dużych spółek notowane na świecie z Francji, Hiszpanii, Niemiec, Belgii, Danii, Polski. Dla tej nielicznej grupy spółek uzyskano odpowiedź, że w większości krajów w latach kryzysu 2007-2009 względnie najwięcej na wartości straciły małe spółki. Mogło to wynikać z ich większej zmienności w porównaniu do spółek dużych i średnich. W najmniejszej liczbie krajów w okresie 2007-2009 względnie najwięcej stracił na wartości indeks średnich spółek. To dlatego, że ma on mniejszą zmienność niż pozostałe indeksy.

\section{WNIOSKI}

W artykule udało się zweryfikować wszystkie postawione hipotezy. W okresie kryzysu badane rynki zachowywały się jak system naczyń połą- 
czonych. Wniosek ten wynika stąd, że wszystkie korelacje pomiędzy ich indeksami giełdowymi były dodatnie, a w grupie 50 wartości współczynnika korelacji pojawiła się tylko jedna wartość nieistotna. Według autorki wystąpił znaczący wzrost korelacji w okresie kryzysu pomiędzy notowaniami uwzględnionych indeksów giełdowych, który jednak mógł być pozorny. Nie zauważono jednak wzrostu zależności pomiędzy indeksami giełdowymi w czasie kryzysu dla pierwszych przyrostów. To ostatnie spostrzeżenie jest zgodne z literaturą. Ze względu na brak zależności ujemnych nie można wnioskować o ucieczkach inwestorów z jednych rynków kapitałowych na inne w badanych okresach. Na zmiany otoczenia w okresie kryzysu subprime najbardziej wrażliwe były małe spółki. Prawdopodobnie wynika to $\mathrm{z}$ ich mniejszej stabilności na giełdzie w stosunku do spółek średnich i dużych. Najmniej straciły względnie na wartości indeksy dużych spółek. Przyczyną może być to, że duże spółki pełniej zarządzają ryzykiem. Na podstawie dopasowania dynamicznych modeli korelacji warunkowej wnioskuje się, że podczas kryzysu nie istniały silniejsze związki między reakcjami instrumentów finansowych na tę samą informację. Na impuls z rynku amerykańskiego najsilniej $\mathrm{w}$ pierwszych trzech okresach zareagowały we wszystkich państwach indeksy dużych spółek, mimo że są one bardziej stabilne na rynku niż indeksy małych spółek. Na drugim miejscu były indeksy średnich spółek, a najsłabiej odpowiedziały indeksy małych spółek. Nie wynika to z niskiej korelacji z indeksem rynku amerykańskiego lub mniejszej zmienności indeksów małych i średnich. DJI reagował podobnie na impulsy wszystkich uwzględnionych indeksów, z niewielką przewagą na rzecz indeksów dużych spółek.

\section{LITERATURA}

Augustyniak H. (2003), Statystyka opisowa z elementami demografii. Przedsiębiorstwo Wydawnicze Ars boni et aequi, Poznań.

Baillie R. T., Kapetanios G. (2013), Estimation and inference for impulse response functions from univariate, strongly persistent processes, „The Econometric Journal”, 16(3), 373-399, DOI: http://dx.doi.org/10.1111/j.1368-423X.2012.00395.x.

Buszkowska E., Płuciennik P. (2013), Wplyw kryzysu subprime na polski rynek kapitałowy, [w:] Kamiński R., Sójka J. (red.), Ekonomiczne i etyczne aspekty kryzysu gospodarczego, PTE, Poznań, 51-62.

Burzała M. (2013), Efekty zarażania wybranych giełd światowych w czasie, „Finanse, Rynki Finansowe, Ubezpieczenia", 6, 51-62.

Dobrzański P. (2010), Transmisja kryzysu amerykańskiego na gospodarki europejskie, http://www.bibliotekacyfrowa.pl/Content/35547/009.pdf, 201-215. (07.04.2010).

Doman M., Doman R. (2014), Dynamika zależności na globalnym rynku finansowym, Difin, Warszawa. 
Doman M., Doman R. (2009), Modelowanie zmienności i ryzyka. Metody ekonometrii finansowej, Wolters Kulwer Polska, Kraków.

Engle R. F. (2002), Dynamic Conditional Correlation: A Simple Class of Multivariate Generalized Autoregressive Conditional Heteroskedasticity Models, „Journal of Business and Economic Statistics", 20, 339-350,

DOI: http://dx.doi.org/10.1198/073500102288618487.

Foster J. B., Magdoff F. (2009), The great financial crisis, causes and consequences, Monthly Review Press, New York.

Juselius K. (2009), The cointegrated VAR model, methodology and applications, Oxford University Press, Oxford.

Kliber A., Kliber P., Płuciennik P. (2012), Zależności pomiędzy stopami procentowymi rynku międzybankowego w Polsce, ,Przegląd Statystyczny”, 149-162.

Kusideł E. (1999), Strukturalne modele VAR i funkcja odpowiedzi na impuls, „Dynamiczne Modele Ekonometryczne", Wydawnictwo UMK, Toruń 1999, 239-254.

Miczka M., Szulc W. (2011), Analiza reakcji na bodźce pomiędzy wybranymi rynkami z wykorzystaniem modelu VAR dla szeregów czasowych cen wyrobów stalowych w latach 1998-2011, Prace IMŻ, 52-62.

Minović J. (2005), Modeling Multivariate Volatility Processes: Theory and Evidence, http://store.ectap.ro/articole/385.pdf, 1-11. (18.10.2005)

Płuciennik P. (2013), The Impact of the World Financial Crisis on the Polish Interbank Market: A Swap Spread Approach, „Central European Journal of Economic Modelling and Econometrics", 269-288.

Przekota G. (2007), Analiza zależności między indeksami rynków akcji na giełdzie polskiej i amerykańskiej, „Badania Operacyjne i Decyzje”, 133-145.

Półkarz R. (2013), Globalne rynki finansowe. Praktyka funkcjonowania. Wydawnictwo Naukowe PWN, Warszawa.

\section{DYNAMIC OF THE MONEY FLOWS BETWEEN STOCK EXCHANGES}

A b s t r a c t. In the article one tried to answer many questions about the money flow between stock exchanges. One reflected if stock markets are a communicating vessels system, if there succeed an escape from one stock exchange to another, if in different periods more lost on the stock markets small, big or medium companies. One searched connections between reactions of different financial instruments on the same information with use of dynamic conditional correlations models. One checked how was the reaction on impulse from American market depending on the quantity of the exchange company from all the world.

$\mathrm{K}$ e y w or d s: stock indexes, volatility, DCC models, impulse response function, crisis. 